\title{
Denosumab Therapy in Giant Cell Bone Tumor: Review of Literature
}

\section{Dev Hücreli Kemik Tümöründe Denosumab Tedavisinin Yeri: Literatürün Gözden Geçirilmesi}

\author{
Orhan Balta ${ }^{1}$, Recep Kurnaz ${ }^{2}$, Kürşad Aytekin ${ }^{3}$, Murat Așçı1 ${ }^{1}$, Mete Gedikbaş ${ }^{1}$, Bora Bostan ${ }^{1}$ \\ ${ }^{1}$ Gaziosmanpaşa Üniversitesi Tıp Fakültesi, Ortopedi ve Travmatoloji A.B.D, Tokat \\ ${ }^{2}$ Acıbadem Hastanesi, Ortopedi Ve Travmatoloji Kliniği, Eskişehir \\ ${ }^{3}$ Giresun Üniversitesi Tıp Fakültesi, Ortopedi Ve Travmatoloji A.B.D, Giresun
}

Dergiye Ulaşma Tarihi: 22.12.2016 Dergiye Kabul Tarihi:21.03.2017 Doi: 10.5505/aot.2017.46036

\section{ÖZET}

Denosumab kemik dev hücreli tümörünü yönetmek için etkili ve kullanışlı bir ilaçtır. İnoperable veya metastatik dev hücreli tümörlü hastalar için birinci basamak tedavide altın standart olarak düşünülmektedir. Dev hücreli kemik tümöründe denosumabınetkinliği prospektifrandomize çalışmalarda kanıtlanmıştır. Nörovasküler yapılara yakın büyük dev hücreli tümörde daha fazla morbiditeye yol açaçak rezeksiyona yönelmek yerine denosumab ile neoadjuvan tedavi dev hücreli tümörde intralezyonel cerrahiyi kolaylaştırabilir. Farklı sebeplerden dolayı tedaviyi bıraktıktan sonra yapılan biyopside psödosarkomatöz değişiklikler görülebileceği unutulmamalıdır. Dev hücreli tümörde denosumab tedavisi sonrası kalınlaşmış korteks ve subkondral kemik içerisinde tümör hücrelerinin gizlenmesi sonucu lokal tümör rekürrensi görülebilir. Denosumab çenede osteonekroz oluşumu ile ilişkilendirilmiştir. Bu makalede denosumab tedavisi alan hastaların sistematik değerlendirilmesi,risk faktörleri, tanı-tedavi yararlığı, tedavi seçeneklerini öngören kılavuzlar sunulmuştur.

Anahtar Kelimeler: denosumab, dev hücreli tümörü, cerrahi

\begin{abstract}
Denosumab is an effective and usefull drug for managing the giant cell bonetumor. It is considered the gold standard for treatment of the inoperable or metastatic giant cell tumors. Theefficacy of denosumab in giant cell bone tumors has been demonstrated in prospective randomized trials. Neoadjuvant therapy with denosumab may facilitate intralesional surgery in giant cell tumor instead of resection leading to more morbidity in a large giant cell tumor close to the neurovascular structure. It should not be forgotten that pseudosarcomatous changes in biopsies may ocur after denosumab treatment due to different reasons. Giant cell tumor may result in dense cortex after denosumab treatment and local tumor recurrence after concealment of tumor cells within the subchondral bone. Denosumab is associated with jaw osteonecrosis formation. In this article, guidelines for systematic evaluation, risk factors, diagnostic-therapeutic usefullness and treatment options for patients treated with denosumab are presented.
\end{abstract}

Keywords: denosumab, giant cell bone tumor, surgery

\section{Giriş}

Dev hücreli kemik tümörü benign fakat lokal olarak agresif davranış gösteren ve genellikle genç erişkinleri etkileyen bir lezyondur (1). Dev hücreli kemik tümöründen etkilenen hastaların \% 1-4 ünde çoğu benign olmak üzere akciğer metastazı görülür $(2,3)$. Dev hücreli kemik tümörleri tüm primer kemik tümörlerinin \% 45'ini ve tüm benign tümörlerin \% 20'sini oluşturur. Kadınlarda 1,5-2 kat daha fazla görülür ve genellikle genç kadınları (20-40 yaş arası) etkiler $(1,4)$. Dev hücreli kemik tümörünün distal femur, proksimal tibia, distal radius ve proksimal humerus en s1k rastlanan tutulum yeridir (5). Aksiyel iskelette en fazla sakrumda görülür $(1,4,5)$. Kemiğin korteksini genellikle inceltir, çoğunlukla ekspanse olur. Yumuşak doku genişlemesi ile veya yumuşak doku genişlemesi olmadan kortekste lizis yapabilir (6). Anterior vertebral kolon tutulumu sikl1kla nörolojik defisit ile prezente olur. \% 1 olgu multifokal tutulum gösterir. \% 10 olgu patolojik kırık ile başvurur. Akciğer metastazı tanıdan ortalama 3-4 yıl sonra ortaya çıkar (2). 
Akciğer metastazı lokal nüks gelişenlerde, distal radius yerleşiminde daha fazladır (2).

Histopatolojik olarak histiositlere benzer neoplastik olmayan (oval/yuvarlak/poligonal) mononükleer stromal hücreler, multinükleer osteoklastik dev hücreler ve mitotik figürler görülür. Atipik mitoz yoktur. Tümör boyunca dağılmış olan çok çekirdekli dev hücreler kemik absorbsiyonundan sorumludurlar. Tek çekirdekli fibröz hücreler oval veya fusiform bir şekle sahiptir (7). Yalnızca proliferatif bir aktivite ve neoplastik sitogenetik anomaliler sunmakla kalmayı aynı zamanda öncül hücrelerden dev hücrelerin oluşumunu ve aktivasyonunu desteklerler (7).

Küretaj ile tedavi edilen Campanacci 3 lezyon, Campanacci 1 veya 2 lezyonlara kiyasla daha yüksek lokal nüks oranları ile ilişkilidir (8, 9). Lokal rekürrens oranı vakaların \% 1950 'sinde olduğu ve genellikle 2 y1lda ortaya çıtı̆̆ 1 bildirilmektedir (10-12). Standart tedavi mümkün olduğunca büyük morbidite olmadan tümörün hemen hemen tamamen çıkarılmasıdır (13). Dev hücreli tümör lezyonlarında tümörün yumuşak dokuları ve eklem kıkırdağını tutulumuna eklenmesi durumunda genellikle etkili bir küretaj mümkün olmaz. İleri dev hücreli tümörde tümör lezyonu basit küretaj için fazla geniş̧ olduğu için ilgili kemiğin ve eklemin enblok eksizyonunu gerektirir (14). Enblok rezeksiyonundan sonra rekürrens riski \% 16'ya kadar düşer. Rekürren dev hücreli kemik tümörü, rezeke edilemeyen tümörler, eklem veya geniş kortikal yıkım ve belirgin yumuşak doku ilişkisi olan tümörlerin tedavisinde öncelikle enblok tümör rezeksiyon sonrasında endoprotez veya allogreft ile defektin rekonstrüksiyonu için endikasyon oluşturabilir. Genç hastalarda belirgin morbiditeye neden olabilir. Rekonstrüksiyon için farklı cerrahi teknikler mevcut olsa da önemli işlevsel bozukluk ve cerrahi morbidite tamamen önlenemez (15). Tedavide küretaj, rezeksiyon veya hatta amputasyona ihtiyaç duyabilir. Çoğu olguda enblok rezeksiyon fazla morbidite ve fonksiyonel bozulmaya sebep olacağ 1 için intralezyoner küretaj tercih edilir (16). Kemik defektinin kemik çimentosu veya kemik grefti ile doldurulmasi ve profilaktik internal fiksasyon yapilır. Adjuvan tedavi olarak ameliyat sırasında kemik çimentosu, fenol, etanol, kriyoterapi veya sonrasinda intravenöz ve oral bisfosfonatların birlikte kullanımı yaygindir $(9,16-19)$.

\section{Denosumab endikasyonları \\ genel \\ kullanım}

Ağır osteoporozda, androjen yoksunluğu tedavisi veya aromataz inhibitörü tedavisine bağlı olarak kırık riski altındaki kişilerde, prostat veya meme kanserine bağlı kemik metastazı olan hastalarda kemik kütlesini arttırmak ve iskeletle ilgili olayların önlenmesi için kullanılmaktadır. Denosumab solid tümörlerden kemik metastazı olan hastalarda iskeletle ilgili olay riskini azaltır ve genellikle iyi tolere edilir. Denosumab, kemik erimesini engeller kemik mineral yoğunluğunu artırır ve kırık riskini azaltır. Denosumab kesilmesi şiddetli bir kemik döngüsü ve hızlı bir kemik mineral yoğunluğu kaybıyla ilişkilidir (20). Postmenapozal osteoporozda denosumab ve teriparatid kombinasyonu kalça ve omurgada kemik mineral yoğunluğunu monoterapiden daha fazla arttırır (21). Denosumab tedavisi lomber ve femoral kemik mineral yoğunluğunu arttırmaktadır. Spinal kord hasarlı bireylerde kemik yıkımı belirteçlerini azaltmaktadır. $\mathrm{Bu}$ ilaç ile spinal kord hasarı ilişkili osteoporozda umut verici bir tedavi seçeneği olabilir (22). Ghermandi ve ark. Denosumab ile tedavi edilen selektif arteriyel embolizasyona yanıt vermeyen vertebral anevrizmal kemik kistinde de kullanılabileceğini ifade etmişlerdir(23).

Thomas ve ark. 2010 yllinda yayınladıkları faz 2 çalışmalarında dev hücreli tümör denosumab tedavisi sonrası radyolojik değerlendirme veya histolojik değerlendirme ile tanımlanan 35 hastanın $30^{\prime}$ unda $\left(\begin{array}{ll}\% & 86\end{array}\right)$ denosumab tedavisine yanıt izlendi (24). Haziran 2013'te dev hücreli tümörü sonucu morbid cerrahi gerektiren veya metastatik hastalığı olan yetişkinlerde kullanılmak için onayı aldı (25). Denosumab metastatik akciğer hastalığının kontrolünde başarıyla kullanılmıştır (26-28).

\section{Denosumab etki mekanizması}

Denosumab reseptör aktivator nükleer faktör kappa b ligand'a (RANKL) karşı tamamen hümanize bir monoklonal antikordur. Reseptör aktivator nükleer faktör kappa B (RANK) ve RANKL osteoklastların oluşumu, fonksiyonu ve sağ kalımı için gereklidir $(24,29)$. Osteoklast benzeri dev hücreler RANK içerir. Denosumab osteoklast aktivitesinin ana aracı olan RANKRANKL etkileşimini inhibe ederek, osteoklast 
maturasyonunu, osteoklast olgunlaşmasını engelleyerek osteoklastla indüklenen kemik yıkımının azalmasına neden olur $(24,30,31)$.

Normal koşullarda osteoblastlar RANKL üretir. Dev hücreli kemik tümörü de RANKL, osteoblastik-tip mononükleer stromal tümör komponenti tarafindan üretilir $(13,32$, 33). Dev hücreli kemik tümörünün neoplastik stromal hücreleri aşırı RANKL eksprese eder. Osteoklast benzeri dev hücreleri aktive eder (32, 34, 35). Dev hücreli kemik tümöründeki denosumab tedavisinin tümör dev hücrelerinin ve neoplastik stromal hücrelerin sayısını azalttı̆̆ 1 ve yeni kemik oluşumuna izin verdiği gösterilmiştir (30). Denosumab tümör stromal hücreleri tarafından sürekli olarak eksprese edilen RANKL ile RANK arasındaki etkileşimi inhibe ederek kemik rezorpsiyonu ve osteolitik tümör genişlemesi progresyonu reversibl olarak bloke olur (36).

Histopatolojik olarak denosumab tedavisi sonrasında proliferatif olmayan yoğun fibröz doku ve yeni kemiğinin oluşumuna ek olarak reaktif osteoklast benzeri dev hücrelerin ( $\geq \%$ 90) güçlü bir şekilde azalması ve azalan neoplastik stromal hücreler görülür (30). Denosumab kitle çevresinde periferik bir rim oluşturarak, intraoperatif kanamayı azaltarak ve kitlenin derecesini agresiften aktif veya latent hastalığa çevirerek cerrah için önemli bir yardım oluşturur (37). Denosumab tedavisi mikrovasküler yoğunluğu azaltarak intraoperatif kanamayı azaltır (37). Watanabe ve ark. denosumabın pelvik dev hücreli tümörde tümör hacmini azaltmanın faydasına ek olarak, intralezyonal küretajından kan kaybını azaltma potansiyeli olduğuna dikkat çekmiştir(38).

Girolamive ark. denosumab ile tedavi edilen tümörlerin neoplastik stromal hücrelerin azalmış anjiyojenezi olan bir fibroz matrise dönüştüğünü göstererek denosumabın tümör vaskülaritesini azalttığını kanıtladılar (39).

Denosumab tedavisi tamamlandiktan sonra oluşan yeni kemiğin sınırları yeniden aktif hale gelebilecek neoplastik hücreler içerebilir (40). Girolami ve ark. denosumabın tümör hücrelerini ortadan kaldırmadığı hipotezini destekleyen tedavi öncesi ve tedavi sonrası kemik dev hücreli tümöründe H3F3A mutasyonunu bulmuşlardır (39).

\section{Denosumab Kemik Dev Hücreli Tümörü Uygulaması}

Tedavinin ilk ayında 8 ve 15 . Günlerinde yükleme dozu sonrası ayda bir subkütan $120 \mathrm{mg}$ denosumab uygulaması önerilmektedir (24). Denosumab subkutan uygulama sonrasi 1 . saatte serumda artar. İlaç 9 ay serumda saptanabilir. Maksimum serum konsantrasyonuna 5-21 günde ulaşır. Plato evresi 20,5 mikrogram/ml 6 ay da ulaşır. Ortalama eliminasyon yarı ömrü 28 gündür. Dubory ve ark. 6 aylik tedaviden sonra denosumabın kemik oluşumuna ve tümör gerilemesine maksimum etkinlik gösterdiğini ifade etmiştir (41).

Osteoklastlar tarafindan salgilanan bir kemik rezorpsiyon markeri olan tartarat dirençli asidfosfataz osteoklastik aktivitenin belirteci olarak kullanılabilir. Bu tür biyolojik belirteçler denosumabın sistemik dolaşımdan tamamen uzaklaştırıldığını ve tekrar eden dönemde tümör nüksünü göstermede yardımcı olabilir(38). Üriner n-telopeptid ve serum c-telopeptid miktarı denosumab tedavisine başlandıktan sonra hızlı düşüş gösterir (24).

Genel olarak denosumab için ameliyat öncesi neoadjuvan kısa bir tedavi yaklaşımı önerilmektedir (42). Denosumab tedavisine yanıt olarak konvansiyonel grafilerde ve tomografide skleroz ve kortikal kemiğin yeniden oluşturulması görülür (43). Tedaviye yanit kriterleri lezyonun boyutunun azalmasi, yumuşak dokunun kalsifikasyonu, sklerozun derecesi, matriks kalsifikasyonu-ossifikasyonu, kortikal septa oluşumu, kortikal kalınlaşma ve subkondral kemik kalınlığı ile değerlendirilir (42). Patolojik yanıt olarak dev hücreler kaybolur. Osteoblast aktivasyonu vardır ancak mitoz yoktur. Immatür kemik oluşumu görülür. RANKL ekspresyonunda azalma saptanır (40). Denosumab tedavisinden sonra florodeoksiglukoz- pozitron emisyon tomografisinde (fdg-pet) azalmış tutulum gözlemlenmektedir. Fdg-pet'in tedaviye cevap için hassas bir gösterge olabileceğini düşündürmektedir (24).

Denosumab ile yapılan tedaviden sonra serum kalsiyumunun izlenmesi şiddetle önerilir. Hipokalsemi, çene osteonekrozu ve atipik kırık,denosumab tedavisinin dikkat gerektiren potansiyel ve önemli toksisiteleridir. 
Toksisiteleri önlemek için, tedavi boyunca kalsiyum ve d vitamini takviyesi önerilir.

\section{Denosumabın Dev Hücreli Tümörde Kullanım Endikasyonları}

Denosumab preoperatif olarak daha az morbid cerrahiye olanak sağlamak için geniş yumuşak doku yay1lımı bulunan tümörleri daha düşük evrelere getirmek için kullanılır $(44,45)$. Yumuşak doku yayılımı ve/veya nörovasküler tutulum nedeniyle primer küretaj mümkün değilse denosumab ile neoadjuvan sistemik hedefli tedavi düşünülmelidir $(24,46)$. Denosumab tedavisi için standart endikasyon kafatas1, omurga veya metastatik tümörler gibi tümörün komple çıkarılamayacağı durumdur $(46,47)$. Mattei C2 omurga gövdesi ve odontoidin dev hücreli tümöründe 16 aylık izlemle denosumab ile başarıyla tedavisini bildirdi (45).

Dev hücreli tümör denosumab tedavisi ilgili faz 2 çalışmada dev hücrelerin $\% 90^{\prime}$ ının histolojik değerlendirmede yok edilmesi, lezyonun radyografik olarak progresyonu olmamas1 hastaların \% 86' sinda (35 hastanın 30' unda) mevcutmuş. Denosumab tedavisine objektif bir yanıt var olarak bildirmişlerdir (24). Chawlas yaptığ 1 çalışmada da denosumabın dev hücreli tümör tedavisinde yüksek etkinliğini teyit etmiştir (46). Chawla ve ark. faz 2 klinik çalışmada ameliyat edilemeyen dev hücreli tümörlü hastalarda yaşam kalitesinde iyileşme ve iyi yanıt olduğunu gösterdi. Daha büyük bir cerrahiye olan ihtiyac1 azalttı, 35 hastanın 30 'unda (\% 86) tümör yanıtı doğrulandı (46). Yüksek cerrahi morbidite bulunan hastaların \% 74'ünde cerrahi ertelenebilmiş. Yüksek cerrahi morbidite bulunan hastaların \% 62'sinde cerrahi düşük evre elde edilmiştir (46).

Müller ve ark. denosumab tedavisi sonras1 \% 40'l1k bir cerrahi "downstaging", gözlemlemişler, büyük rezeksiyon oranını \% 64 ' den \% 24' e düşürmüşler. Ayrıca hiçbir evre düşüşü olmayan hastalarda cerrahi işlem intraoperatif kanamayı azaltığı için ve artmış kemik yoğunluğu intraoperatif manipülasyonu basitleştirdiği için cerrahiyi kolaylaştırmıştır $(30,48)$. Bu vakalarda radyoterapiyi gereksiz hale getirebilir, denosumab intralezyonel ameliyatlara izin verebilir.

Rekhi ve ark. çoğu durumda osteoklast benzeri dev hücrelerin kaybolmasına yol açan denosumabı, çoğunlukla büyük boyutlu, sınırda kurtarılabilir vakalarda cerrahi prosedürünün morbiditesini azaltmak için önermişlerdir (3). Chawla ve ark. yaptığı çalışmada inoperabl dev hücreli tümör olgularında olguların \% 96'sında progresyonu engellediğini göstermiştir (46).

\section{Denosumab ve Sarkomatöz Değişim}

K1smen tedavi edilen dev hücreli tümörünün histolojik değerlendirilmesindeki güçlükler mevcuttur (49). Sanchez-parej ve ark. denosumab tedavisi alan distal ulnadaki dev hücreli kemik tümörü vakalarında histolojik psödosarkomatöz değişiklikler gösterdiler (49). Wojcik ve ark. denosumab ile tedavi edilen dev hücreli tümör hastalarında yapılan histolojik incelemede osteosarkom ile histolojik benzerliğini vurgulamışlardır (50). Fakat dev hücreli kemik tümörü $\mathrm{CDK} 4$ ve $\mathrm{mdm} 2$ amplifikasyonunun olmamas1 nedeniyle osteosarkomdan histolojik olarak ayırt edilebilir (51). H3F3A geninin 3.3 histon mutasyonlar1 son zamanlarda kemik dev hücreli kemik tümöründe tanımlanmıştır ve zorlu vakalarda tanıyı aydınlatmada faydalı olabileceğini kanıtlamıştır (47).

Zhang ve ark. yaptıkları çalışmada çok çekirdekli osteoklastik dev hücrelerin ortadan kalkması mononükleer tümör hücrelerinin çoğalması, osteoit birikimi ve yeni kemik oluşumu sonrasında lezyonun konvansiyonel bir dev hücreli tümörden çok farklı bir yapıya sahip olabileceğini bildirmişlerdir. Çok çekirdekli osteoklastik dev hücrelerin kaybolmasi sonrasinda osteoblastoma benzer içeriğe sahip olan, histolojik ve radyografik açıdan belirgin bir fibrovasküler stroma içerisinde yeni kemik oluşumunun görüldüğü bir ara dönem görülür. $\mathrm{Bu}$ yüzden çalışmalarında bu ara devrenin patologlar, radyologlar ve cerrahlar için yanıltıcı̆̆ olabileceği ve ara dönemin farkında olmaları gerektiğini vurgulamışlardır (52).

Zhang ve ark. tek başına denosumab tedavisinin için uygun bir tedavi olmadığını ifade etmişlerdir (52). Literatürdeki birçok çalışmada cerrahi gerçekleştirilmeksizin tek başına denosumab kullanımı yerine tümör cerrahisi öncesinde kısa dönemli denosumab kullanımı önerilmektedir.

Park ve ark. yaptığı çalışmada pelvik dev hücreli tümörlü hastada 20 ay denosumab terapi sonrası rezeksiyon uygulanmış. 7 ay sonra, hastanın ilk lezyon alanındaki 
osteosarkomun yanı sira pulmoner metastaz olduğu tespit edilmiş fakat diğer çalışmalarla uyuşmamaktadır. Post-denosumab ile tedavi edilen dev hücreli tümör olguları histopatolojik incelemede düşük dereceli osteosarkom olarak görülmekle birlikte bir osteosarkomun klinik davranışından yoksun olduğundan, bu nedenle psödomalign kemik lezyonlar olarak düşünülmelidir (3). Denosumab tedavisi erken döneminde yapılan biyopsilerde kemikdeki histolojik değişiklikler osteosarkom taklit edebilir. Tedavi edilen tümörler tedavi öncesi dev hücreli tümöre çok az benzerlik gösterdiğinden, tedavide önemli bir etkiye sahip olan yanlış tanıdan kaçınmak için denosumab uygulamasının öyküsüne dikkat edilmelidir. Osteosarkomdan farklı olarak mdm2 negatiftir ve infiltratif bir büyüme paterninden yoksundur (50). Bir H3F3A p.g34w'nin tanımlanmas1 başlangıç dev hücreli tümör tanısında en tutarlı, dev hücreli tümör tanısına için son derece hassas ve spesifiktir. H3F3A ekson 2 p.G34 noktasının varlığı maligniteyi ekarte ettirmez. Zira p.G34 H3F3A mutasyonları 2/116 osteosarkomda ve malign osteoklastta tanımlamışlardır(49).

\section{Denosumab Tedavisi Sonrası Dev Hücreli Tümörde Tekrarlama}

Rekürrens tedaviyi bıraktıktan genellikle 7-9 ay sonra içinde ortaya çıkar. Denosumab tedavisinden vazgeçmenin yüksek oranda tümör rekürrensi ile ilişkili olduğu konusunda büyük bir endişe vardır (53). Zoledronik asit, neoplastik stromal hücreler tarafindan RANKL'nin mRNA ekspresyonunu inhibe ederken, denosumab bu etkiye sahip değildir. Lau ve arkadaşlarının denosumabın dev hücreli tümör stromal hücre dizileri üzerinde sadece minimal inhibitör etkiye neden olduğunu ve herhangi bir apopitoza neden olmadığını savunmaktadir (54). $\mathrm{Bu}$ denosumabin kesilmesinden sonra tekrarlamanın meydana gelebileceği hipotezini güçlendirmektedir. Girolami ve ark. ilacın tümör hücrelerini ortadan kaldırmadığı hipotezini destekleyen tedavi öncesi ve tedavi sonrası kemik dev hücreli tümöründe H3F3A mutasyonunu bulmuşlardır. Mak ve ark. dev hücreli kemik tümörü hücre kültürlerini inceledi ve denosumab ile muamele edilen örneklerin herhangi bir dev hücre görmediler, ancak neoplastik stromal hücrelerin devam ettiğini ve tedavi edilmemiş dev hücreli tümöre göre daha yavaş da olsa çoğalmaya devam ettiğini keşfetti (53).

Denosumab tedavisi sonrası oluşan sert, fibröz, sklerotik dokunun intralezyonel küretaj1 oldukça zordur (40). Denosumab periferik bir rim oluşturarak ve aşamayı agresiften aktif veya latent hastalığa çevirerek onkolojik cerraha yardımcı olabilir. Canlı tümör hücrelerinin kalması nedeniyle akut tedavi edilebilen bir hastalığının kronik bir hastalığa çevirebilir (37, 42). Denosumab tedavisinden sonra gelişen septaların duvarında canlı hücreler kalabilir tümör hücreleri yeni oluşan kemikte kaldığından dolayı küretajın cerrahi tekniği, daha yüksek lokal nüks oranları önlemek için daha agresif olarak uygulanmalıdır (37). Yeniden kemikleşmiş bölgelerde kalan tümöre ulaşmak için ve lokal kontrolün artırılması için intraoperatif yüksek hızlı burr kriyoterapi ,fenol, sıvı azot kullanımı önerilmektedir $(9,16$, $55,56)$.

222 hastayı değerlendiren faz II klinik çalışmada ameliyat sonrası hastaların çoğunluğu 6 ay boyunca adjuvan denosumab ald. Cerrahi geçiren 116 hastanın (sadece 13 aylik ortalama cerrahi sonrası takip) 17 ' sinde (\% 15) lokal nüks mevcuttu ve bu hastaların büyük çoğunluğunda sadece intralezyoner cerrahi ile tedavi edildiler (57).

İn vitro çalışmalar dev hücreli kemik tümörünün denosumaba tepki verdiğini göstermektedir. Denosumab tedavisi kesildikten sonra dramatik tümör yeniden büyümesi bildirilmiştir (58). Farklı sebeplerden dolayı tedaviyi bıraktıktan sonra dev hücreli tümörün tekrarlanması sonrasında denosumabın yeniden kullanılması etkili bir seçenek gibi gözükmektedir (59). Borkowska ve ark. bazı vakalarda denosumab tedavisi sirasinda tümör ilerlemesi gözlemlemişlerdir (60).

\section{Denosumab Yan Etkileri}

Denosumab kullanımında bildirilen ciddi advers olaylar arasında şiddetli hipokalsemi, çene osteonekrozu ve atipik stres kırıkları bulunmaktadır (46). Stopeck ve ark. zolendronik asit ve denosumab1 karşılaştıdıkları çalışmada hipokalsemi oranları benzerdi. İki ilaç içinde çene osteonekrozu saptand1 (61). Çene osteonekrozu riskinin denosumabin füzyonlarının süresi ve miktarı ile arttığı bildirilmiştir (62). Deoliveira 
ve ark. yaptığ 1 çalımada çene osteonekrozu vakalarının en fazla 60 yaş ve üstü kadın hastalarda meydana geldiği sonucuna varmıştır. En çok etkilenen bölge mandibula posterioru olarak bulunmuştur (63).

Şiddetli hipokalsemik olaylar zoledronik asit ile karşılaştırıldığında denosumab tedavisinden sonra daha s1k ortaya çıktığını saptayan yayınlarda mevcuttur (64). Denosumab parathormonu (PTH) yükseltir(65).

Böbrek transplantasyonundan sonraki ilk yılda enfeksiyonların görülme sıklığı ve şiddeti üzerine bu ilacin etkisini değerlendirdikleri çalışmada böbrek nakli sonrasında kemik kaybını önlemek için bir yıl denosumab tedavisi alan hastalarda üriner sistem infeksiyonlarının daha sik görüldüğü bildirmiştir $(49,66)$.

Denosumab gebe kalmayı isteyen kadınlarda, büyük bir endişe kaynağı olacaktır, zira denosumabın hayvanlar üzerinde artmış ölü doğum ve azalmış büyüme ile ilişkili olduğuna dair kanıt vardır. Denosumab kullanan kadınların ilaç kullanırken uygun kontraseptif önlemleri almaları önerilir (67).

Sonuç olarak, yumuşak doku tutulumu yaygın olan dev hücreli kemik tümörü (Campanacci 3) ve aksiyel iskelet kemiklerindeki dev hücreli kemik tümörü tedavisi daha zordur ve daha yüksek lokal tekrarlama oranları olduğu bildirilmiştir $(8,68$, 69). Omurga ve kafatasının dev hücreli tümörü hayati yapıların yakın olması nedeniyle inoperable olarak kabul edilebilir ve ameliyatla tümörün tamamen çıkarılması imkansızdır (69, 70). Denosumab zor vakalarda tümör yükününü azaltmak için kullanılmaktadır. Farklı sebeplerden dolayı tedaviyi bıraktıktan sonra dev hücreli tümörün tekrarlayabileceği, tedavi alan hastalarda biyopsi tekrarı durumunda sarkamotöz değişikliklerin görülebileceği akılda tutulması gerekmektedir. Denosumab tedavisi alan hastalarda periferik bir rim oluşturarak ve aşamayı agresiften aktif veya latent hastalığa çevirmesine rağmen, septalarda canlı tümör hücersi görülebileceği, yeniden kemikleşmiş bölgelerde kalan tümöre ulaşmak için ve lokal kontrolün artırılması için intraoperatif yüksek hızlı burr kriyoterapi, fenol, sıv1 azot kullanımı gerektiği unutulmamalıdir.
Çıkar çatışması: Yazarlar çıkar çatışması beyan etmemişlerdir.

\section{Referanslar}

1. Picci PM MM, Fabbri N, Gambarotti M, Vanel D. Atlas of musculoskeletal tumors and tumorlike lesions. 1 edn. Cham heidelberg dordrecht london new york: springer international publishing; 2014.

2. Siebenrock KA, Unni KK, Rock MG. Giant-cell tumour of bone metastasising to the lungs. A long-term follow-up. J Bone Joint Surg Br. 1998;80(1):43-7.

3. Rekhi B, Verma V, Gulia A, Jambhekar NA, Desai S, Juvekar SL, et al. Clinicopathological Features of a Series of 27 Cases of Post-Denosumab Treated Giant Cell Tumors of Bones: A Single Institutional Experience at a Tertiary Cancer Referral Centre, India. Pathol Oncol Res. 2016.

4. Thomas DM, Skubitz KM. Giant cell tumour of bone. Curr Opin Oncol. 2009;21(4):338-44.

5. Vigorita V. Orthopedic pathology. 2nd ed. Philadelphia,Pa: wolters kluwer/lippincott williams \& wilkins; 2008

6. Resnick D KM, Greenway GD. Tumors and tumor-like lesions of bone: imaging and pathology of specific lesions. Diagnosis of bone and jointdisorders. 3rd ed. Philadelphia: saunders; 1995. P. 3628-3938.

7. Cowan RW, Singh G. Giant cell tumor of bone: a basic science perspective. Bone. 2013;52(1):238-46.

8. Prosser GH, Baloch KG, Tillman RM, Carter SR, Grimer RJ. Does curettage without adjuvant therapy provide low recurrence rates in giant-cell tumors of bone? Clin Orthop Relat Res. 2005(435):211-8.

9. Gaston CL, Bhumbra R, Watanuki M, Abudu AT, Carter SR, Jeys LM, et al. Does the addition of cement improve the rate of local recurrence after curettage of giant cell tumours in bone? J Bone Joint Surg Br. 2011;93(12):1665-9.

10. Brinklov S, Kalko EKV, Surlykke A. Intense echolocation calls from two 'whispering' bats, Artibeus jamaicensis and Macrophyllum macrophyllum (Phyllostomidae). J Exp Biol. 2009;212(1):11-20.

11. Balke M, Schremper L, Gebert C, Ahrens H, Streitbuerger A, Koehler G, et al. Giant cell tumor of bone: treatment and outcome of 214 cases. J Cancer Res Clin Oncol. 2008;134(9):969-78.

12. Klenke FM, Wenger DE, Inwards CY, Rose PS, Sim FH. Giant cell tumor of bone: risk factors for recurrence. Clin Orthop Relat Res. 2011;469(2):591-9.

13. Skubitz KM. Giant cell tumor of bone: current treatment options. Curr Treat Options Oncol. 2014;15(3):507-18.

14. Szendroi M. Giant-cell tumour of bone. J Bone Joint Surg Br. 2004;86(1):5-12. 
15. Enneking WF, Dunham W, Gebhardt MC, Malawar M, Pritchard DJ. A system for the functional evaluation of reconstructive procedures after surgical treatment of tumors of the musculoskeletal system. Clin Orthop Relat Res. 1993(286):241-6.

16. van der Heijden L, Dijkstra PD, van de Sande MA, Kroep JR, Nout RA, van Rijswijk $\mathrm{CS}$, et al. The clinical approach toward giant cell tumor of bone. Oncologist. 2014;19(5):550-61.

17. Gouin F, Rochwerger AR, Di Marco A, Rosset P, Bonnevialle P, Fiorenza F, et al. Adjuvant treatment with zoledronic acid after extensive curettage for giant cell tumours of bone. Eur J Cancer. 2014;50(14):2425-31.

18. Jones KB, DeYoung BR, Morcuende JA, Buckwalter JA. Ethanol as a local adjuvant for giant cell tumor of bone. Iowa Orthop J. 2006;26:69-76.

19. Tse LF, Wong KC, Kumta SM, Huang L, Chow TC, Griffith JF. Bisphosphonates reduce local recurrence in extremity giant cell tumor of bone: a case-control study. Bone. 2008;42(1):68-73.

20. Lamy O, Gonzalez-Rodriguez E, Stoll D, Hans D, Aubry-Rozier B. Severe reboundassociated vertebral fractures after denosumab discontinuation: nine clinical cases report. J Clin Endocrinol Metab. 2016:jc20163170.

21. Tsai JN, Uihlein AV, Burnett-Bowie SM, Neer RM, Derrico NP, Lee H, et al. Effects of Two Years of Teriparatide, Denosumab, or Both on Bone Microarchitecture and Strength (DATA-HRpQCT study). J Clin Endocrinol Metab. 2016;101(5):2023-30.

22. Gifre L, Vidal J, Carrasco JL, Muxi A, Portell E, Monegal A, et al. Denosumab increases sublesional bone mass in osteoporotic individuals with recent spinal cord injury. Osteoporos Int. 2016;27(1):405-10.

23. Ghermandi R, Terzi S, Gasbarrini A, Boriani S. Denosumab: non-surgical treatment option for selective arterial embolization resistant aneurysmal bone cyst of the spine and sacrum. Case report. Eur Rev Med Pharmacol Sci. 2016;20(17):3692-5.

24. Thomas D, Henshaw R, Skubitz K, Chawla S, Staddon A, Blay JY, et al. Denosumab in patients with giant-cell tumour of bone: an open-label, phase 2 study. Lancet Oncol. 2010;11(3):275-80.

25. Goldenberg MM. Pharmaceutical approval update. P T. 2013;38(8):443-5.

26. Demirsoy U, Karadogan M, Selek O, Anik Y, Aksu G, Muezzinoglu B, et al. Golden bullet-denosumab: early rapid response of metastatic giant cell tumor of the bone. J Pediatr Hematol Oncol. 2014;36(2):156-8.

27. Gossai N, Hilgers MV, Polgreen LE, Greengard EG. Critical hypercalcemia following discontinuation of denosumab therapy for metastatic giant cell tumor of bone. Pediatr Blood Cancer. 2015;62(6):1078-80.

28. Karras NA, Polgreen LE, Ogilvie C, Manivel JC, Skubitz KM, Lipsitz E. Denosumab treatment of metastatic giant-cell tumor of bone in a 10-year-old girl. J Clin Oncol. 2013;31(12):e200-2.

29. Steensma MR, Tyler WK, Shaber AG, Goldring SR, Ross FP, Williams BO, et al. Targeting the giant cell tumor stromal cell: functional characterization and a novel therapeutic strategy. PLoS One. 2013;8(7):e69101.

30. Branstetter DG, Nelson SD, Manivel JC, Blay JY, Chawla S, Thomas DM, et al. Denosumab induces tumor reduction and bone formation in patients with giant-cell tumor of bone. Clin Cancer Res. 2012;18(16):4415-24.

31. Xu W, Li X, Huang W, Wang Y, Han $\mathrm{S}$, Chen S, et al. Factors affecting prognosis of patients with giant cell tumors of the mobile spine: retrospective analysis of 102 patients in a single center. Ann Surg Oncol. 2013;20(3):80410 .

32. Huang L, Xu J, Wood DJ, Zheng MH. Gene expression of osteoprotegerin ligand, osteoprotegerin, and receptor activator of NFkappaB in giant cell tumor of bone: possible involvement in tumor cell-induced osteoclastlike cell formation. Am $\mathrm{J}$ Pathol. 2000;156(3):761-7.

33. Roudier MP K-GK, Huang LY. Rank and rankl expression in giant cell tumours of the bone: an immunohistochemical study. 12th annual connective tissue oncology society meeting; nov 2-4, 2006; venice, italy.

34. Atkins GJ, Kostakis P, Vincent C, Farrugia AN, Houchins JP, Findlay DM, et al. RANK Expression as a cell surface marker of human osteoclast precursors in peripheral blood, bone marrow, and giant cell tumors of bone. $\mathrm{J}$ Bone Miner Res. 2006;21(9):1339-49.

35. Thomas DM. RANKL, denosumab, and giant cell tumor of bone. Curr Opin Oncol. 2012;24(4):397-403.

36. Kim Y, Nizami S, Goto H, Lee FY. Modern interpretation of giant cell tumor of bone: predominantly osteoclastogenic stromal tumor. Clin Orthop Surg. 2012;4(2):107-16.

37. Muller DA, Beltrami G, Scoccianti G, Campanacci DA, Franchi A, Capanna R. Risks and benefits of combining denosumab and surgery in giant cell tumor of bone-a case series. World J Surg Oncol. 2016;14(1):281.

38. Watanabe N, Matsumoto S, Shimoji T, Ae K, Tanizawa T, Gokita T, et al. Early evaluation of the therapeutic effect of denosumab on tartrate-resistant acid phosphatase $5 \mathrm{~b}$ expression in a giant cell tumor of bone: a case report. BMC Res Notes. 2014;7:608.

39. Girolami I, Mancini I, Simoni A, Baldi GG, Simi L, Campanacci D, et al. Denosumab treated giant cell tumour of bone: a morphological, immunohistochemical and molecular analysis of a series. J Clin Pathol. 2016;69(3):240-7.

40. Gaston CL, Puls F, Grimer RJ. The dilemma of denosumab: Salvage of a femoral head giant cell tumour. Int J Surg Case Rep. 2014;5(11):783-6. 
41. Dubory A, Missenard G, Domont J, Court C. Interest of Denosumab for the Treatment of Giant-cells Tumors and Aneurysmal Bone Cysts of the Spine. About Nine Cases. Spine (Phila Pa 1976). 2016;41(11):E654-60.

42. Traub F, Singh J, Dickson BC, Leung $\mathrm{S}$, Mohankumar $\mathrm{R}$, Blackstein $\mathrm{ME}$, et al. Efficacy of denosumab in joint preservation for patients with giant cell tumour of the bone. Eur J Cancer. 2016;59:1-12.

43. Chakarun CJ, Forrester DM, Gottsegen CJ, Patel DB, White EA, Matcuk GR, Jr. Giant cell tumor of bone: review, mimics, and new developments in treatment. Radiographics. 2013;33(1):197-211.

44. Agarwal A, Larsen BT, Buadu LD, Dunn J, Crawford R, Daniel J, et al. Denosumab chemotherapy for recurrent giant-cell tumor of bone: a case report of neoadjuvant use enabling complete surgical resection. Case Rep Oncol Med. 2013;2013:496351.

45. Mattei TA, Ramos E, Rehman AA, Shaw A, Patel SR, Mendel E. Sustained longterm complete regression of a giant cell tumor of the spine after treatment with denosumab. Spine J. 2014;14(7):e15-21.

46. Chawla S, Henshaw R, Seeger L, Choy E, Blay JY, Ferrari S, et al. Safety and efficacy of denosumab for adults and skeletally mature adolescents with giant cell tumour of bone: interim analysis of an open-label, parallelgroup, phase 2 study. Lancet Oncol. 2013;14(9):901-8.

47. Behjati S, Tarpey PS, Presneau N, Scheipl S, Pillay N, Van Loo P, et al. Distinct $\mathrm{H} 3 \mathrm{~F} 3 \mathrm{~A}$ and $\mathrm{H} 3 \mathrm{~F} 3 \mathrm{~B}$ driver mutations define chondroblastoma and giant cell tumor of bone. Nat Genet. 2013;45(12):1479-82.

48. Hakozaki M, Tajino $\mathrm{T}$, Yamada $\mathrm{H}$, Hasegawa $\mathrm{O}$, Tasaki $\mathrm{K}$, Watanabe $\mathrm{K}$, et al. Radiological and pathological characteristics of giant cell tumor of bone treated with denosumab. Diagn Pathol. 2014;9:111.

49. Sanchez-Pareja A, Larousserie F, Boudabbous S, Beaulieu JY, Mach N, Saiji E, et al. Giant Cell Tumor of Bone With Pseudosarcomatous Changes Leading to Premature Denosumab Therapy Interruption: A Case Report With Review of the Literature. Int J Surg Pathol. 2016;24(4):366-72.

50. Wojcik J, Rosenberg AE, Bredella MA, Choy E, Hornicek FJ, Nielsen GP, et al. Denosumab-treated Giant Cell Tumor of Bone Exhibits Morphologic Overlap With Malignant Giant Cell Tumor of Bone. Am J Surg Pathol. 2016;40(1):72-80.

51. Chow LT. Giant cell rich osteosarcoma revisited-diagnostic criteria and histopathologic patterns, Ki67, CDK4, and MDM2 expression, changes in response to bisphosphonate and denosumab treatment. Virchows Arch. 2016;468(6):741-55.

52. Zhang Y, Zheng Y, Xiong W, Peng C, Zhang Y, Duan R, et al. Morphological Transformation between Nanocoils and
Nanoribbons via Defragmentation Structural Rearrangement or Fragmentation-recombination Mechanism. Sci Rep. 2016;6:27335.

53. Mak IW, Evaniew N, Popovic S, Tozer R, Ghert M. A Translational Study of the Neoplastic Cells of Giant Cell Tumor of Bone Following Neoadjuvant Denosumab. J Bone Joint Surg Am. 2014;96(15):e127.

54. Lau CP, Huang L, Wong KC, Kumta SM. Comparison of the anti-tumor effects of denosumab and zoledronic acid on the neoplastic stromal cells of giant cell tumor of bone. Connect Tissue Res. 2013;54(6):439-49.

55. Gortzak Y, Kandel R, Deheshi B, Werier J, Turcotte RE, Ferguson PC, et al. The efficacy of chemical adjuvants on giant-cell tumour of bone. An in vitro study. J Bone Joint Surg Br. 2010;92(10):1475-9.

56. Malawer MM, Bickels J, Meller I, Buch RG, Henshaw RM, Kollender Y. Cryosurgery in the treatment of giant cell tumor. A long-term followup study. Clin Orthop Relat Res. 1999(359):176-88.

57. Rutkowski P, Ferrari S, Grimer RJ, Stalley PD, Dijkstra SP, Pienkowski A, et al. Surgical downstaging in an open-label phase II trial of denosumab in patients with giant cell tumor of bone. Ann Surg Oncol. 2015;22(9):2860-8.

58. Silpa Poola-Kella SES, Scott E. Strome and Elizabeth A. Streeten. . Sat-341: giant cell tumor of the bone: combined treatment with denosumab and zolendronic acid.(2016)

59. Gaston CL, Grimer RJ, Parry M, Stacchiotti S, Dei Tos AP, Gelderblom H, et al. Current status and unanswered questions on the use of Denosumab in giant cell tumor of bone. Clin Sarcoma Res. 2016;6(1):15.

60. Borkowska A, Goryń T, Pieńkowski A, Wągrodzki M, Jagiełło- Wieczorek E, Rogala P, et al. Denosumab treatment of inoperable or locally advanced giant cell tumor of bone. Oncology Letters. 2016;12(6):4312-8.

61. Stopeck AT, Fizazi K, Body JJ, Brown JE, Carducci M, Diel I, et al. Safety of long-term denosumab therapy: results from the open label extension phase of two phase 3 studies in patients with metastatic breast and prostate cancer. Support Care Cancer. 2016;24(1):44755.

62. Kajizono M, Sada H, Sugiura Y, Soga Y, Kitamura Y, Matsuoka J, et al. Incidence and Risk Factors of Osteonecrosis of the Jaw in Advanced Cancer Patients after Treatment with Zoledronic Acid or Denosumab: A Retrospective Cohort Study. Biol Pharm Bull. 2015;38(12):1850-5.

63. de Oliveira CC, Brizeno LA, de Sousa FB, Mota MR, Alves AP. Osteonecrosis of the jaw induced by receptor activator of nuclear factor-kappa B ligand (Denosumab) - Review. Med Oral Patol Oral Cir Bucal. 2016;21(4):e431-9.

64. Kinoshita Y, Arai M, Ito N, Takashi Y, Makita N, Nangaku M, et al. High serum ALP level is associated with increased risk of 
denosumab-related hypocalcemia in patients with bone metastases from solid tumors. Endocr J. 2016;63(5):479-84.

65. Dempster DW, Zhou H, Recker RR, Brown JP, Recknor CP, Lewiecki EM, et al. Differential Effects of Teriparatide and Denosumab on Intact PTH and Bone Formation Indices: AVA Osteoporosis Study. J Clin Endocrinol Metab. 2016;101(4):1353-63.

66. Bonani M, Frey D, de Rougemont O, Mueller NJ, Mueller TF, Graf N, et al. Infections in de novo kidney transplant recipients treated with the RANKL inhibitor denosumab. Transplantation. 2016.

67. Bussiere JL, Pyrah I, Boyce R, Branstetter D, Loomis M, Andrews-Cleavenger $\mathrm{D}$, et al. Reproductive toxicity of denosumab in cynomolgus monkeys. Reprod Toxicol. 2013;42:27-40.

68. Leggon RE, Zlotecki R, Reith J, Scarborough MT. Giant cell tumor of the pelvis and sacrum: 17 cases and analysis of the literature. Clin Orthop Relat Res. 2004(423):196-207.

69. Martin C, McCarthy EF. Giant cell tumor of the sacrum and spine: series of 23 cases and a review of the literature. Iowa Orthop J. 2010;30:69-75.

$70 . \quad$ Bhatia S, Miszczyk L, Roelandts M, Nguyen TD, Boterberg T, Poortmans P, et al. Radiotherapy for marginally resected, unresectable or recurrent giant cell tumor of the bone: a rare cancer network study. Rare Tumors. 2011;3(4):e48. 